Attila Csaba KONDOR

Dániel HORVÁTH

\section{Challenges and experiences of a participative green space development in Budapest-Józsefváros}

\section{Introduction}

Urban green spaces should be crucial elements of the cities, because green spaces and green space improvement play a key role in urban development. Contrarily, green spaces of the downtown of Budapest remained neglected in the last decades (Ongjerth, 2008; Schneller, 2008; Tózsa, 1995). The quality of life in Budapest is significantly impaired by the fact that the per capita ratio of green areas in densely populated city quarters is extraordinarily low and most of the existing green spaces are run-down (Egedy, 2008).

Due to the city's geographical characteristics the large hills on the Buda side within the city borders offer precious little positive attractions to people living in the centre or the districts on the Pest side. The areas covered with vegetation have rapidly declined during the several hundred years of development inside the city, and by now there are hardly any large green spaces in the centre. With detached houses gradually gaining ground, by now forest land has decreased significantly even on the Buda side, but the differences in the size of green areas is still striking: while the per capita green area in the city of Budapest is $0.3 \mathrm{~m}^{2}$, this value is 123 $\mathrm{m}^{2}$ in District XII, on the northwestern fringe of Budapest. The districts have taken very few steps to increase the size and improve the quality of public spaces and parks covered with vegetation. The downtown districts of Budapest lack any strategy for the development of green spaces, and the issue of green areas is often the last item on the list of urban development concepts (Berényi et al., 2008).

A lot of official and public initiatives have been demonstrated the growing importance of green spaces first of all in densely built up urban areas. Municipality of Budapest approved the reviewed mid-term urban development programme in 2007 which suggested to set up the long-term urban green development strategy for Budapest and for each district. Some priorities were built in the so called Podmaniczky Programme (the name of the mid-term development programme for Budapest). Establishing Urban Green Strategy as a programme element is included in the Priority for an Environmental Awareness Budapest. The City of Budapest and the districts will have to define the preferential projects which are able to catalyze the urban renewal activities, e.g. avenue reconstruction programme, establishing new parks and gardens, wood development, Green Danube Programme to elaborate a promenade along the river Danube, creak revitalization programme, the green ring programme and green development programmes in the rust belt.

District VIII of Budapest (known as Józsefváros; Joseph's Town) is situated in Pest side in the vicinity of city centre, that is one of the most diverse residential areas of Budapest. The prestige of this district reduced in the last decades, the shrinking of the population was persistent and the process of segregation occurred. Some integrated urban development programs have been set up by the local government of Józsefváros after 2000, because negative urban processes (in particular criminality and prostitution) became intolerable. Since the public spaces were generally neglected, each of the integrated development programme contains an emphatic public and, of course, green space development element (Alföldi and Kovács, 2008).

This article focuses upon the Magdolna Quarter Programme of Józsefváros that contains the details of the rehabilitation of this area attaches great importance to the renewal of physical environment. Renewing of the green public spaces was one of the different separate sub-programs supported by European Union in frame of INTERREG IIIB Cadses - GreenKeys Project (GreenKeys: urban green as a key for sustainable cities). After reviewing of the physical and social patterns of Magdolna Quarter and Mátyás square the authors will explain the aims and measures of the integrated Magdolna Quarter Programme and say something about the implementation of GreenKeys Project.

One of the most important target areas of Magdolna Quarter Programme is the Mátyás square and its neighbourhood. The subprogramme that nails its flag to the mast of the rehabilitation of this green space aims at improving the residential neighbourhood by means of green rehabilitation that actively involves the people, thereby rebuilding and strengthening the local society. The main goal was the improving of the quality of life by the help of the tools of green development. The first phase of this sub-programme comprises the renewal of Mátyás square through the participation of the local residents and actors. The acknowledged planners adopt namely as well, that "Involvement of citizens may also not only improve programmes, but may influence the positions of the participants themselves: the participation process may increase social contacts and social cohesion between people, thereby decreasing processes of social exclusion" (Wassenberg et al., 2007: 13).

Renewed green space has been created in Mid-Józsefváros through the renewal of Mátyás square that may be seen by the people living there as a space of their own and used for different purposes in accordance with its true function. This is all the more important because apart from Kálvária square this is the place in the quarter that can be the most suitable for meeting the needs of residents for green surfaces. The green space development has been implemented by Rév8 Zrt. (Rév8 Urban Renewal and Development of Józsefváros Plc.), the non-profit local project management company of District VIII and GRI HAS (Geographical Research Institute of Hungarian Academy of Sciences), and the presented results have been produced by both organisations. 


\section{Urban features of Józsefváros and Magdolna Quarter}

Józsefváros is located in the centre of Pest, next to the city. The district is divided into 11 spatial units (so called identification-quarters, each with an independent image of its own) by the "15-year Development Strategy for the District Józsefváros" in 2004 (Figure 1).
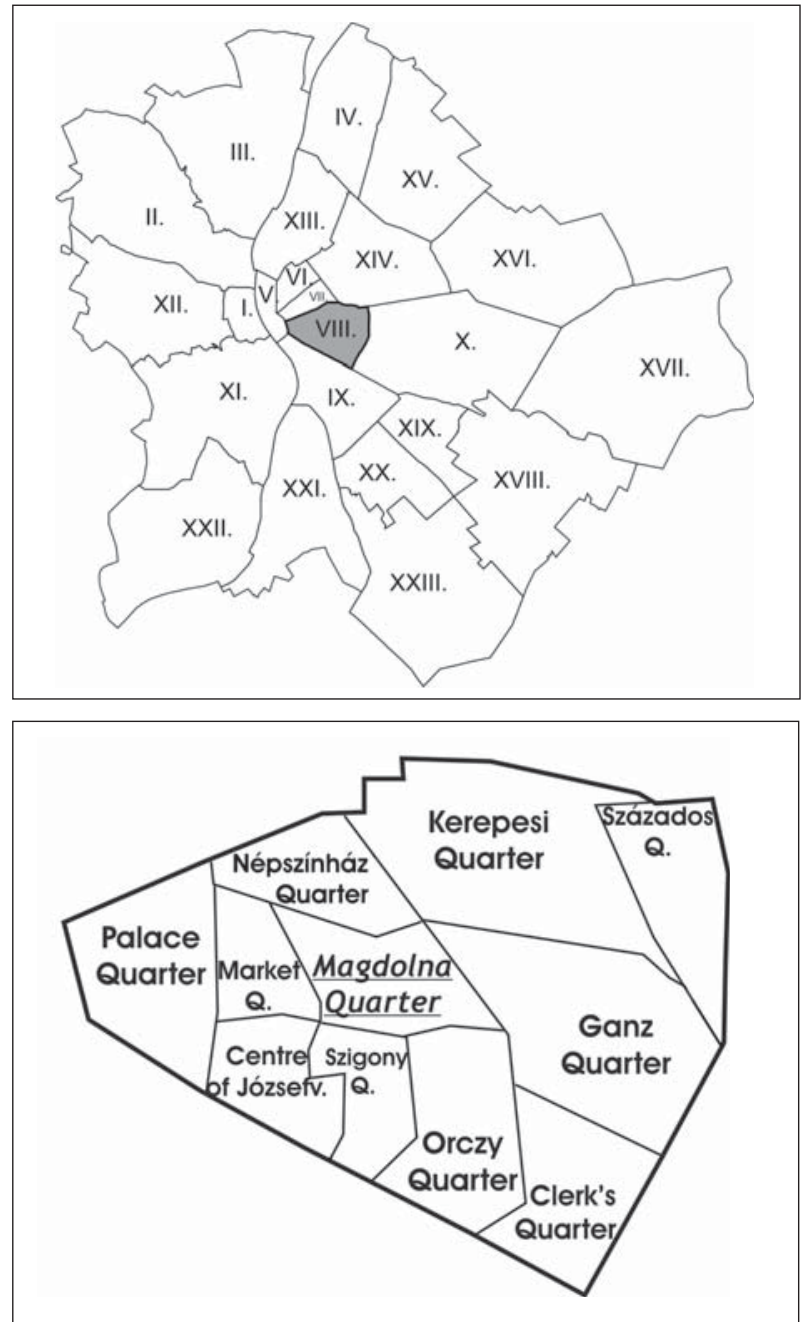

Figure 1: Location and quarters of Józsefváros (source: B. Szabó, A. Cs. Kondor (GRI HAS)).

First of all, Józsefváros can be featured by a bit dissimilar patterns from the other districts, but the circumstances are expressly disadvantegous. The urban tissue of Józsefváros is one of the most diversified areas in Budapest. Palace Quarter is the most attractive part of the district, which includes to the high-developed and aesthetical downtown, but brownfield areas and deteriorated residential areas extended into the heart of the district suffered by different social problems and conditions. Therefore Józsefváros had the most negative image inside the territory of the Hungarian capital until 2000, the district could be characterized by decreasing of population, ruined houses, high criminal rates etc. Process of segregation has speeded up, number of Romas has increased rapidly. In particular the position of Magdolna Quarter (one of the 11 identification-quarters of Józsefváros) became very hopeless, the unemployment rate was equally the highest all over Budapest and the proportion of economically active population was the lowest. Additionally the public spaces and green surfaces were enormally run-down.

Though a part of the area gained a terrible reputation in the 1980's and 1990's, the district itself includes a number of areas of high prestige, such as the neighborhood, with its aristocratic palaces housing some of the highly ranked cultural institutes of the city, and for example, a residental area (Tisztviselötelep/Clerk's Quarter) on the fringe of the district, originally occupied by clerks working in administration. Nevertheless these prestigeous buildings are less characteristic of the district than those situated in Mid-Józsefváros and consisting of small flats practically without all the modern conveniences, because from the 1910's there were hardly any new constructions, and, due to continually postponed refurbishing, it slowly began to deteroriate (Bajomi, undated).

The processes of migration were disadvantegous in the last decades. Underclass families (mainly Romas) settled into the deteriorating middle part of the district from the beginning of the 1970's from the underdeveloped eastern region of Hungary, that induced a stronger tendency of segregation. From the 1970's, due to segregation and explosive suburbanisation the population of the district rapidly decreased (Figure 2), and the criminality got out of control until the turn of the millennium.

Based on the recognition of the challenges, Local Government of Józsefváros and Municipality of Budapest decided to implement a notable project for a comprehensive reconstruction of Mid-Józsefváros in PPP-construction at the end of the 1990's in order to change the image of the district (Internet 1). A 220.000 square meter area have been involved in the so called Corvin Promenade Programme and the new quarter will be a new prestigious heart of the district, the rundown condominiums have been demolished and replaced by a new multifunctional city centre.

However, the design of the project area reflects the ideas of investors, the local residents aren't involved into the project so deeply, nevertheless this is the first vast complex urban development programme in the district due to the social elements. A new green axle demonstrates the new identity of the redeveloped quarter and underpins the importance of the urban green. Creating of new urban green spaces were also a major priority, but due to the multifarious problems has required to start an other, more integrated urban renewal programme in the district, and Magdolna Quarter was appointed for the first model area of the social urban rehabilitation of Józsefváros.

Magdolna Quarter is a residential area with closed rows of buildings mostly built at the turn of the 20th century, which had seen better times before and which became a critical area after World War II due to the gradual deterioration of the building and housing stock and the social devaluation of the area (Egedy, 2008). In the next section of the paper we will review the main demographic features of Magdolna Quarter as well as the problems that affect the situation of 


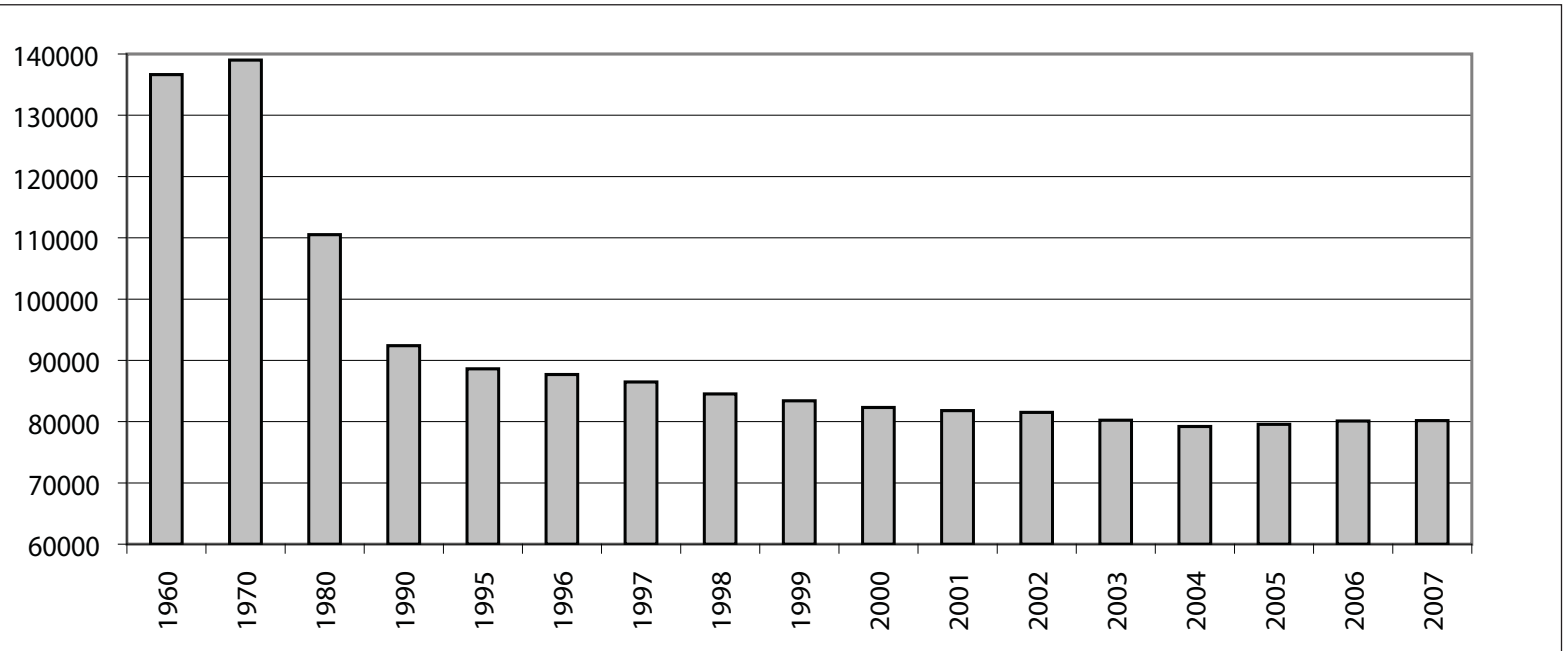

Figure 2: Population of Józsefváros (source: Hungarian Central Statistical Office).

green spaces, using the the results of questionnaire surveys and scientific analyses of Erdősi (2007) and Egedy (2008).

Magdolna Quarter includes $15 \%$ of the district's population, approximately 12.000 people. By age the population of the quarter is younger than that of the district. The ratio of economically active population (40\%) is lower but that of the unemployed is somewhat higher (13\%) than in the entire Józsefváros. The most alarming problem of Magdolna Quarter is the extremely high ratio of people with low school qualification: nearly $40 \%$ of the population aged 15 to 60 only completed 8 years of primary school.

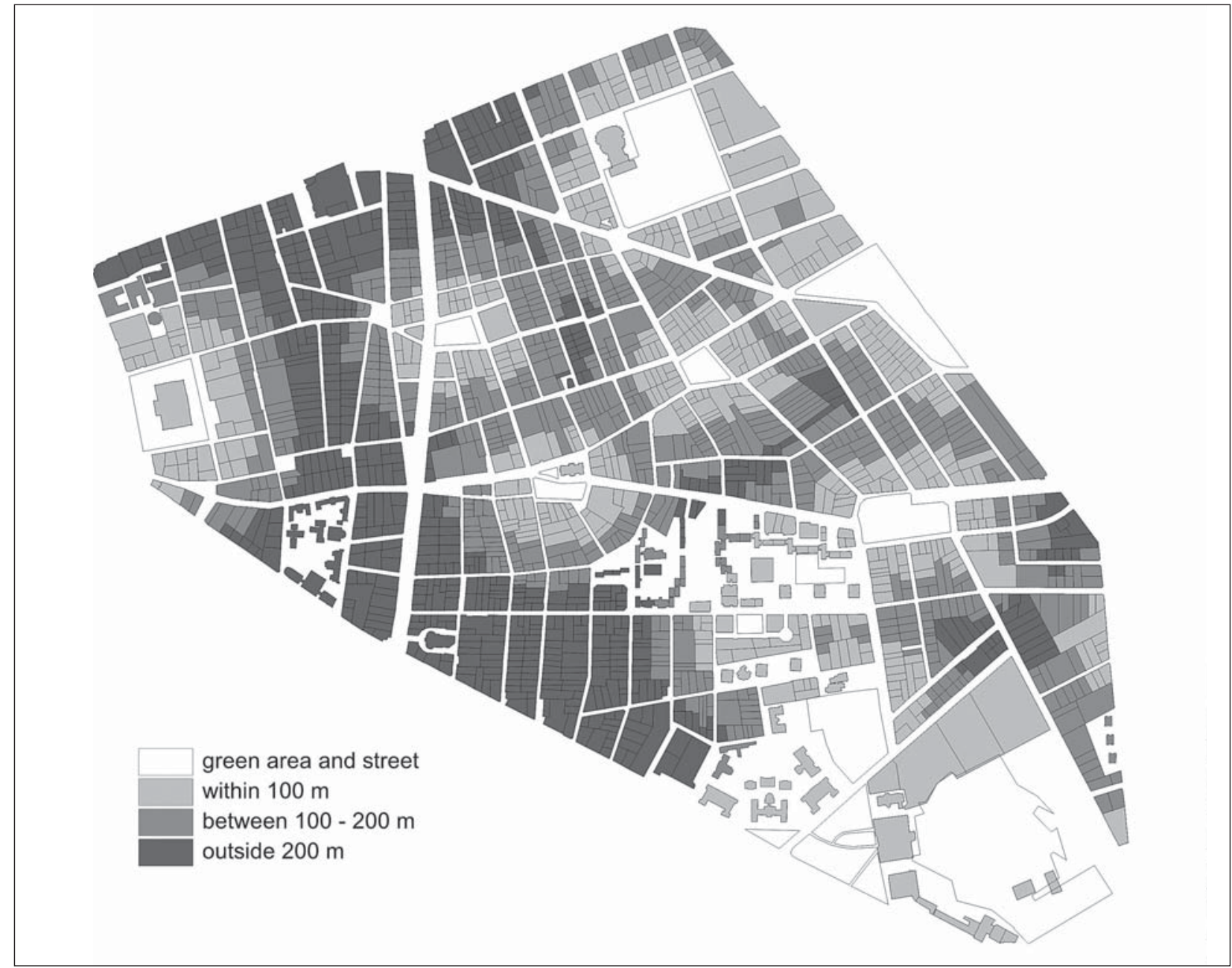

Figure 3: Green space availability in Inner- and Mid-Józsefváros (source: B. Szabó (GRI HAS)). 
According to the 2001 census there are 5564 flats and occupied premises not meant for residential purposes. According to the survey conducted in $200738 \%$ of the housing stock is in municipal ownership (Egedy, 2008). The showy high ratio of one-roomed flats and flats without basic amenities or limited amenities continues to be a major problem in Magdolna Quarter (the ratio of flats with all or basic amenities was only $79 \%)$.

The questionnaire surveys of Erdősi and Egedy demonstrated that the building and housing stock in Mátyás square and its broader neighbourhood have rather unfavourable indicators. This is supported by data showing that half of the respondents live in a flat smaller than $40 \mathrm{~m}^{2}$ with one room, which can ensure less favourable living conditions than the average as far as the quality of life is concerned, due to the high ratio of overcrowded homes. The basic area exceeds $80 \mathrm{~m}^{2}$ only in $11.6 \%$ of the flats included in the survey. The situation is further worsened by the fact that one-fourth of the households included in the survey have a toilet outside the flat and in $14.5 \%$ of them there is no bathroom facility. The flats owned by the municipality most likely represent a high percentage in the entire housing stock (over $40 \%$ in Magdolna Quarter).

Józsefváros lacks green spaces, and most of them are rundown (Figure 3). As a result of extensive urban policy after the Second World War the quality of the already neglected squares and parks (e. g. Kálvária square, Mátyás square) deteriorated further. Several surveys were implemented by Rév8 and GRI HAS regarding the local and adjacent green surfaces, and the results were considerably disillusioned. More than two-thirds of the respondents believed that the term "disastrous" fully or partly fits the condition of green spaces in their residential environment, but the opinions were improved after the implemention of the renewal of Mátyás square (Berényi et al., 2008). Obviously, the quality of the environment in general was not rated as the important reason for the intention to migrate, although the bad condition of the environment had the weakest influence on the intention to migrate in the case of people living in Magdolna Quarter. The intention to migrate in this area is determined more by social conditions and the quality of the built environment, while the rest of the central sample areas are in a better position in this respect.

Nevertheless it can be mentioned, that the processes of the housing market today show that green areas have an important place in the opinion of people about their place of residence. The most dynamic zones include the conurbanation and the garden city quarters of Budapest with detached houses, bungalows and smaller owner-occupied blocks, while the densely built-in parts of the city centre with much less green surfaces constitute an area where population continues to decrease further (Dövényi and Kovács, 1999; Beluszky, 2007). Naturally, this does not mean that the quality of green spaces is the primary criterion when selecting a home; however, as is shown by the survey, the majority of respondents classify the quarters with family houses and villas as the most sought-after areas of all quarters with a high prestige. So, a complex, integrated development of a deteriorated quarter is unimaginable without renewal of green surfaces.

\section{Aims and features of Magdolna Quarter Programme}

City is a multiple system constantly changing, therefore its development can only be influenced by similarly complex and integrated programmes. This is of particular importance in case of this deteriorated quarter as well, which isn't even capable of staying on his feet on his own power, not even talking about making one step ahead. Magdolna Quarter Programme is a first trial in Hungary to implement renewal of a multiple retarded urban district with the involvement of the residents including integrated social, cultural and technical measures (Magdolna Quarter Programme, 2007). As it was mentioned above, the Local Government of Józsefváros accepted the plan of integrated social urban regeneration in 2004. Rév8 developed the comprehensive programme for Magdolna Quarter, as a mid-term regeneration initiative for a 15-year-period. The process takes place as a cooperation between Municipality of Budapest and Local Government of Józsefváros, the key words of this urban regeneration programme are cooperation and participation. Magdolna Quarter demands sophisticated tools of regeneration which take all three fields of society, economy and environment into consideration in the target area, achieving a higher efficiency with the help of several programmes run parallel to each other, linked on a number of points, having a positive impact on one another.

The model programme has got a general purpose, three special aims and practicable projects. This general purpose is the introducing of an urban rehabilitation scheme in Hungary where all programme elements are built upon the active involvement of those living in the quarter. It should act as a catalyst for the pubic initiatives and thereby create a unique shaped and attractive part of the city with creating new public and cultural spots and renewal of the existing ones. The social aim incorporates to improve the standard of living by ensuring appropriate living conditions by involvement of the current residents, by strengthening the local community cohesion and by retaining the social diversity. The economic aim contains the improving of the earnings production and self-reliance of the quarter, development of the local labour market and thereby reduction of the lasting unemployment. At last but not at least, the environmental aim covers the enlarging and developing of public and green areas both by size and quality, creating sustainable living environment by continuous renewal of buildings in small steps, by retaining the architectural values and by building new houses (Magdolna Quarter Programme, 2007).

The aura of urban green space development has been proven (Making greener cities, 2004). It has social, ecological and economic effects as well, and the planners reckon with this by renewal of Mátyás square. Renewed public areas that are enriched by quality green areas are key to liveable urban areas, therefore the attractive, varied and flexibly usable inner urban spaces are essential for neighbourhoods and their residents (Table 1). Experts have demonstrated that with their positive effect on air pollution and the microclimate green spaces may trigger certain social and economic processes (Boros, 1993; Zahnen, 2004). 
Table 1: Functions and effects of green spaces.

\begin{tabular}{|l|l|}
\hline Social function and effect & Ecological function and environmental effect \\
\hline Offers healthier living conditions & Promotes the protection of environmental resources \\
\hline Holds a key role in recreation & Improves biodiversity \\
\hline Improves urban life quality (dwelling, work, leisure) & $\begin{array}{l}\text { Improves urban climate (air cleanliness, noise- and shake } \\
\text { protection, drainage etc.) }\end{array}$ \\
\hline Scene of communal relations, meeting place (e.g.: cultural events) & Diminishes the air pollution \\
\hline Environmental awareness & Mitigate enviromental stress \\
\hline Scene of communal relations, meeting place (e.g.: cultural events) & Aspects of planning and development \\
\hline Important factor in choosing sites & Defines city structure \\
\hline Strengthens local economy & Defines city character and cityscape \\
\hline $\begin{array}{l}\text { Promotes tourism and investment } \\
\text { Scene of communal relations, meeting place (e.g.: cultural events) } \\
\text { imanagement) }\end{array}$ & Improves the balance between nature and architecture \\
\hline Improves employment in both direct and indirect ways (maintenance, & $\begin{array}{l}\text { Integrates the city into its natural surroundings by its } \\
\text { network }\end{array}$ \\
\hline
\end{tabular}

Source: Making Greener Cities (2004)

\section{Fundraising}

City planners and developers haven't launched in Hungary any similar urban regeneration programs yet. Magdolna Quarter Programme was set up with an experimental phase in 2005, and this segment was accomplished in 2008. The regeneration takes place based on the co-operation and co-financing of City of Budapest and Local Government of Józsefváros. The total budget of the pilot phase is 3.1 million euro. This model thus adjusts to the challenges caused by the administrative and local governance model of Budapest where service delivery, finances etc. is shared between two elected levels: the decentralized local government and the Budapest level. It has been recognized that any action in the framework of the two-tier government system shall involve both levels of government (Józsefváros Magdolna Negyed Szociális Városrehabilitáció Program/Józsefváros Magdolna Quarter Programme of Social Urban Rehabilitation, 2005).

The total budget of the green space development was 200.000 euro, and six financial sources were available for the implementation of renewal of Mátyás square. The best part of budget came form Municipality of Budapest, this contributions were totaled up to approximately two tierce of the total budget. Other important parts belonged to Local Government of Józsefváros and to GreenKeys Project. Some parts came from the VÁTI Interreg Department (Hungarian Management Authority; in cofinancing of GreenKeys Project), the ASTUTE Project and of course from Rév8 Plc. This type of multi-source financing is not common in Hungary. In addition, non-calculated added values were achieved by public participation in the implementation phase, for example the planting of Mátyás square was partly accomplished by local residents free of charge.

\section{Role of the GreenKeys project}

Public green space development of the Mátyás square was not merely first action area of Magdolna Quarter Programme for Rév8 Plc., at the same time it was a pilot project area of the GreenKeys Project in partnership with GRI HAS as well as with Corvinus University and also of the ASTUTE (Advancing Sustainable Transport in Urban areas To promote Energy efficiency), supported by the European Union.

Mátyás square was partly renewed in 2002 but this work didn't restored the original functions of the area. The square could be caracterized by considerable concentration of homeless people and high rate of prostitution. The small playground with some benches didn't constitute a popular place in the low quality vegetation milieu, and the square didn't offered any other recreational facilities.

Rév8 and GRI HAS wanted to develop a 'Place' for the community which contributes to the increase of the resident retention force of the neighbourhood and to the enhancement of the living standards: two key targets of the whole neighbourhood regeneration project. The targets were defined, and the renewal accomplished with unbroken involvement of the local community which could create and maintain a community place at the end that could become a meeting location for different social groups at the same time and with the feeling of ownership. As a result of the successful programme elements, Mátyás square has turned into an integrating and identity re-building location in the area and the district. The cohesion of the local residents has strengthened not only because the square is re-utilised by the residents but also through their involvement into the design and implementation of the new green area.

Establishing channels and collaboration forms as well as revitalizing the existing ones among the different stakeholders were the missions of the experimental period of the regeneration activities. The most important task was to make up the lack of dialogue among separated sectors (local government, civil organizations, institutes, citizens, enterprises, etc.) in order to set up new bridges among different urban stakeholders and to enhance the confidence (Horváth and Teller, 2008). 


\section{Steps of the renewal process}

By the introduction of Magdolna Regeneration Programme and Greenkeys Project the goals and actions were revised in 2005. The main goal of the revised renewal activity was the creation of high quality and well-maintained urban green space with new public functions in the former run-down Mátyás square (Figure 4). The preparation and the implementation phases of the pilot project were accomplished from 2005 until March 2008 including the public discussions on demands and expectations of local residents (Table 2). The experience shows that the whole progress should be shorter than we used.

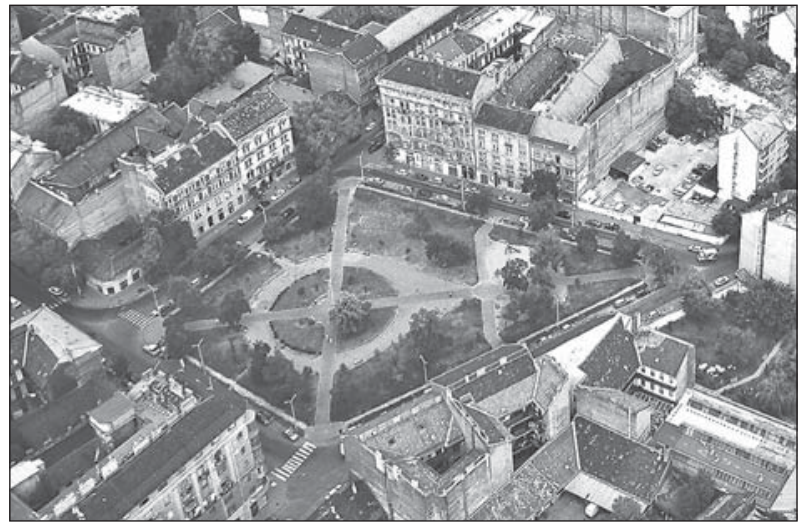

Figure 4: The view of run-down Mátyás square in 2005 (source: local government of Budapest Józsefváros, Bureau of the Chief Architect - air photo).

Table 2: Phases of preparation and implementation.

\begin{tabular}{|l|l|}
\hline Preparation stage & Event \\
\hline Date & Kick off meeting \\
\hline $\begin{array}{l}\text { November 2005 - } \\
\text { March 2006 }\end{array}$ & Surveys (Rév8 and GRI HAS) \\
\hline $\begin{array}{l}\text { February and March } \\
2006\end{array}$ & Meetings with local residents \\
\hline March 2006 & $\begin{array}{l}\text { Cooperation between Corvinus } \\
\text { University and Józsefváros }\end{array}$ \\
\hline March 2006 & Presenting the concepts in meetings \\
\hline May 2006 & Presenting the final plan \\
\hline September 2006 & Finalising the planning \\
\hline Implementation stage & \\
\hline December 2006 & Creating sitting-hills \\
\hline April 2007 & Establishing the new space structure \\
\hline November 2007 & Renewing the green surfaces \\
\hline 22. April 2008 & Opening ceremony \\
\hline
\end{tabular}

\subsection{Preparation}

The preparation phase was a long-term period with parallel initiatives that at the end joined in the implementation. The initial communication activities of Rév8 were launched in October 2005 by distributing coulourful leaflets and organizing a "kick-off" meeting for the residents. Two further meetings with the public were held a few months later, in February and March 2006, all were announced in the local newspaper. Besides these conversations about the local needs what to establish and how to renew the square a survey was carried out by Rév8 and GRI HAS in the months at the end of 2005 and the beginning of 2006. One of the most important messages both from the consultations and the survey was that $80 \%$ of the affected public would happily participate in the implementation and the maintenance phase.

March 2006 was the next milestone in the renewal process: an agreement was signed about the cooperation on the planning and implementation of the project between the Corvinus University and the Municipality of Józsefváros. During this month, based on the comments and demands of the local inhabitants, three different concepts were developed that were presented in the meeting held in the mid of March, where both the professional and the public were participated. Planning was carried out in evidence - students came around, carried out researches on the history, population, role etc. of Mátyás square, made interviews with local inhabitants. At the end, based on the comments received in March, one final plan was developed and presented to the public in May. The presentation was organized in the framework of an open-air gathering, demo and communication materials were widely applied.

After the discussions the phase of planning was closed in the 3rd quarter of the year 2006, the Local Government of Józsefváros prepared the implementation plans and changed the master plan accordingly. The final plans were presented to the public in the framework of the "Health-day" in September, because it is a very popular event in the district.

\subsection{Implementation}

The implementation activity was divided into two parts. The first stage which was financed by the GreenKeys was commenced in December 2006 by creating so-called sitting-hills for the square as an alternative to benches. Pupils of one of the schools of Magdolna Quarter, local NGO's and students

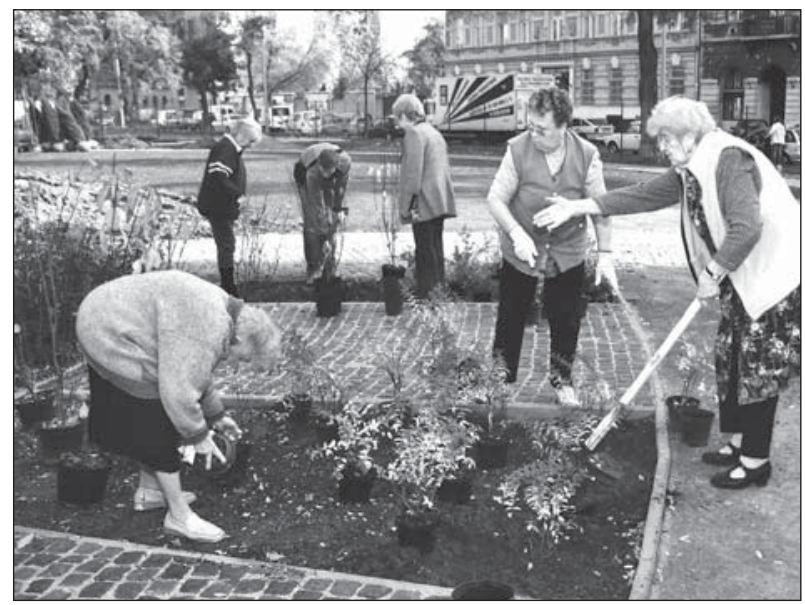

Figure 5: Public Planting in Mátyás square in 2007 (source: Rév8 Zrt., Nyári Gyula). 
of the Corvinus University were participated in this action. By the mid of April 2007, the new structures (pathways, main green spot, etc.) were established. The new pavement was constructed according to the previously explored demands. Replanting was organized and placing the sitting-hills was carried out with public participation in two days during spring 2007.

The second phase of the implementation comprised establishing a new playground and fences, new public lighting and security service. New plants were placed on the square by residents, politicians and NGO's during two days of voluntary work in autumn 2007 (Figure 5)

\subsection{Finalisation and the future}

The finalisation of the green development process was in accordance with the general mission of the project. The opening ceremony of the new green space was involved in a huge open-air public programme by Rév8 and GRI HAS on the Day of Earth, in 22. April 2008 (Figure 6); Mátyás square is guarded day and night.

During the next phase of Magdolna Regeneration Program, the surrounding streets will get a changed function - thus, the project affecting Mátyás square will go on and the square will be strengthened in its function as axis of development processes. Rév8 and GRI HAS would like to extend the public participation methodes to the maintenance activities as well. Several local meetings were organized in connection with the role of potencial stakeholders in the maintenance period. It is in progress to delegate the different tasks for the local institutes and communities.

\section{Evolved Tools}

\subsection{Urban Green Space Strategy (UGSS)}

In frame of GreenKeys Project Rév8 and GRI HAS elaborated the Urban Green as a first tool of green space development of Józsefváros. The document supplements the Integrated Urban Development Strategy of Józsefváros - IVS) which aims at resolving economic, environmental and social problems concentrated in urban areas. Since current Hungarian regulations on area management and environment protection do not elaborate on green surface strategy, the realization of the present document - in a normative sense - cannot be enforced directly. Nevertheless it is a crucial proposal to draw attention to the essential nature of developing and maintaining squares and parks in order to improve the state of environment in Józsefváros. The document also intends to set an example to other settlements. Green space development plays an ever-increasing role of in urban redevelopment, thus UGSS can help the urban redevelopment objectives to be more versatile (Horváth et al., 2008).

After summary of designation and validity of the strategy the document profoundly analises and summarizes the environmental condition and challenges of Józsefváros, and points

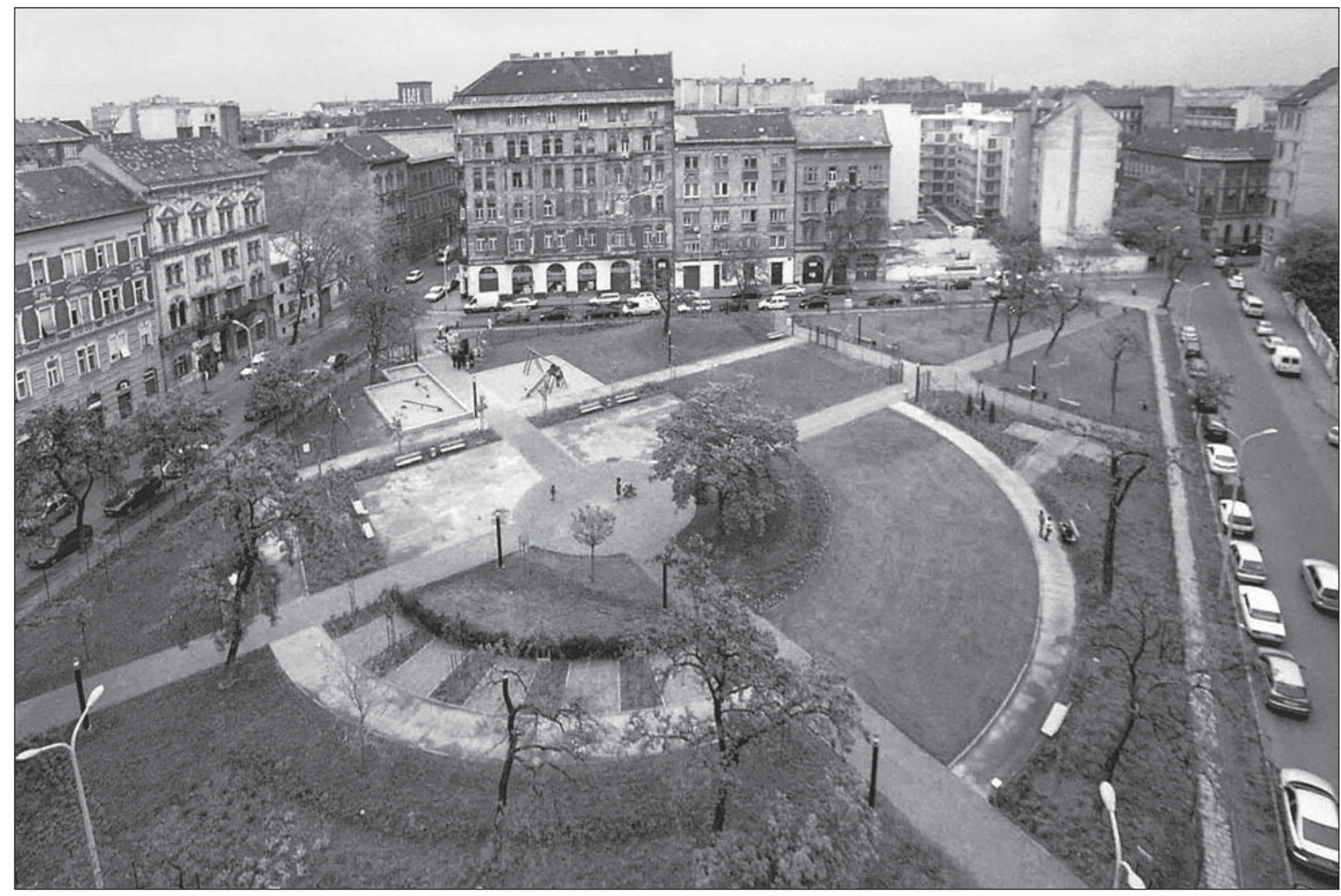

Figure 6: The renewed Mátyás square in 2008 (source: Rév8 Zrt., Nyári Gyula). 
out that one of the most essential problem of the district is the lack of easily available and groomed green spaces. Hence five priorities have been compiled in the strategy: protection of green spaces, revaluation, improvement of availability, creating new green spaces and improvement in participation. Besides protection the revaluation of the green spaces is essential. The strategy emphasises, that new green spaces should be created, especially in the redevelopment areas. A main goal would be to make these squares and parks available to everybody so that green spaces should not function only as places for Józsefváros gangs to meet and for dogs to walk. In order to meet the listed priorities, participation is needed, an optimal level of public involvement in the protection and possible development of green spaces cannot be circumvented. The goals, the related 12 actions and the action plan of UGSS underpin the priorities, and help for the actors to implement concrete green space development. Finally, the strategy presents the elements of the green space monitoring as well as the green space audit.

\subsection{GreenKeys Monitoring System}

One of the main objectives of the GreenKeys Project was to create a monitoring tool that is especially geared to monitoring the implementation of new or the improvement of existing urban green spaces. The monitoring of green spaces means to track continuously whether the planned objectives of the project are being fulfilled. Continuous monitoring activity is essential for the successful implementation of an integrated urban green structure renewal. Through monitoring, the project executors get information about fulfilled objectives, the status of the project in hand. They will also know about delays and reasons for delays. Monitoring is a project-oriented activity and it is absolutely necessary for the successful implementation of an actual project as it tracks the whole procedure (Horváth et al., 2008).

GreenKeys Monitoring System (GMS) was created as a tool that should be relatively easily used by experts and nonprofessionals, with comprehensible and numeric indicators (Egedy 2008). A monitoring system is a combined entity containing all the tools, arrangements, corporations, organisations and institutions required to carry out the monitoring of a project. The monitoring process starts with data collection, then follows the systematising, interpreting and carefully analysing of data. The results of analyses should be summarised in a monitoring report, then through the use of the information and results that are presented in this report the development of the project can be evaluated. GMS helps to control self given targets during the whole implementation process of a green space project. The computer program was written in $\mathrm{C}++$ language and the relatively simple software offers basic options (data input, rating indicators, saving, printing) for monitoring. GMS contains two basic sheets. The front page is suitable for inputting the main objectives and actions (i.e. interventions, activities) of the project. Indicators, to be measured during monitoring, can be selected here as well. The evaluation sheet is of use for the evaluation of simple indicators and it helps to follow up both the development and efficiency of the actions to be carried out and the realisation and success of the main objectives. The GreenKeys Monitoring System will be available on the CD-ROM of GreenKeys Manual.

\section{Conclusion}

The reviewed local green space development project could present a new pattern of practice regarding the urban renewal in Hungary. Rév8 and GRI HAS had been able to introduce a project from an other aspect of urban public space development, they accomplished a pioneer project with all of its occurrent mistakes. It could be appreciated as a result to make the local citizens be interested in the renewal of urban environment and to involve the local stakeholders into the process in an underdeveloped quarter. It was a very useful consequence to collaborate a non-profit urban renewal project company (Rév8) and a research institute (GRI HAS) together, the two organisations could product very practicable tools for urban green development (e. g. urban green space strategy and monitoring system).

Due to the poor local conditions the imperfections could be expected because redeveloping a green space is not the most important priority from the resident's point of view. Finding partners, involving residents and motivating stakeholders are more difficult in a run-down part of the city than in a well-conditioned other one. According to most useful experience the definition of limited goals is very important as Rév8 and GRI HAS accomplished; people use the green spaces and people think about the local environment.

The public participation can be successful just with very intensive previous and mid-term information flow. It is an impossible initiation to involve all of local people into the progress but we have to aim to do it. Regarding the public participation our results were unexpectedly good, but a twoyear-progress should be ideal for the project.

Dr. Attila Csaba Kondor, Lawyer and Geographer

Geographical Research Institute of Hungarian Academy of Sciences (GRI HAS), Budapest

E-mail: attilacsaba.kondor@gmail.com

Dániel Horváth, Geographer

Rév8 Urban Renewal and Development of Józsefváros Plc., Budapest E-mail: horvath-daniel@rev8.hu

\section{References}

Alföldi, Gy., and Kovács, Z. (2008) The future of our cities - joint responsibility and joint green action, in: Alföldi, Gy., and Kovács, Z. (eds.) Városi Zöld Könyv - Urban Green Book, pp. 100-103. Budapest, ÉTK, MTA FKI, Rév8 Zrt.

Bajomi, I. (undated) Education of underprivileged children in a deteriorated neighborhood of Budapest. Available at: http://www.girsef.ucl.ac.be/bajomi.pdf (Date accessed, 02. 09. 2008).

Beluszky, P. (2007) A Kárpát-medence régiói6. Közép-Magyarország (Regions of Carpathian Basin 6. Middle-Hungary). Pécs-Budapest, Dialóg Campus.

Berényi, E., Kondor, A. Cs., and Szabó, B. (2008) The social aspects of green areas in Budapest with special regard to migration questionnaire research in six sample areas, in: Alföldi, Gy., and Kovács, Z. (eds.) Városi Zöld Könyv Urban Green Book, pp. 104-121. Budapest, ÉTK, MTA FKI, Rév8 Zrt. 
Boros, T-né (1993) Városi zöldterületek társadalmi haszna és költsége (The social benefit of urban green spaces). Budapest, Országos Múszaki Információs Központ és Könyvtár.

Dövényi, Z., and Kovács, Z. (1999) A szuburbanizáció térbeni-társadalm jellemzői Budapest környékén (Spatial-social features of suburbanisation around Budapest). Földrajzi Értesítő (Geographical Bulletin), 48(1-2), pp. 33-57.

Egedy, T. (2008) The expected impact of the rehabilitation of Mátyás square on the local community and the quality of life, in: Alföldi, Gy., and Kovács, Z. (eds.) Városi Zöld Könyv - Urban Green Book, pp. 122-146. Budapest, ÉTK, MTA FKI, Rév8 Zrt.

Egedy, T. (2008) The role of monitoring and the Greenkeys Monitoring System, in: Urban Green Spaces - A Key for Sustainable Cities: Conference Reader. Dresden, Leibniz Institute of Ecological and Regional Development.

Erdősi, S. (2007) A monitoring-rendszer jelentése. Jelentés: Budapest Józsefváros Magdolna Negyed Program I. jelenlegi állásáról és monitoring vizsgálatáról (Meaning of monitoring system - A report about the present position and monitoring survey of Budapest Józsefváros Magdolna Quarter Programme I. Budapest, Rév8 - Józsefváros Rehabilitation and Urban Development Company.

Horváth, D., Kondor, A. Cs., and Tózsa, I. (2008) Proposition for the Strategy of Budapest-Józsefváros, in: Alföldi, Gy., and Kovács, Z. (eds.) Városi Zöld Könyv - Urban Green Book, pp. 179-195. Budapest, ÉTK, MTA FKI, Rév8 Zrt.

Horváth, D., and Teller, N. (2008) Experiences of an urban regeneration model - Participatory planning and implementation in Józsefváros, Magdolna Quarter, in: Alföldi, Gy., and Kovács, Z. (eds.) Városi Zöld Könyv Urban Green Book, pp. 147-154. Budapest, ÉTK, MTA FKI, Rév8 Zrt.
Hungarian Central Statistical Office. Statistical Yearbooks of Hungary 1961-2007. Budapest, Hungarian Central Statistical Office.

Internet 1: http://www.corvinpromenade.com (Date accessed, 2. 9 2008).

Józsefváros Magdolna Negyed Szociális Városrehabilitáció Program (Józsefváros Magdolna Quarter Programme of Social Urban Rehabilitation) (2005) Available at: http://www.rev8.hu/csatolmanyok/proj_dokok/ proj_dokok_5.pdf

Magdolna Quarter Programme (2007) Regeneration Programme in Budapest - Józsefváros, Magdolna Quarter Programme. Budapest, Rév8 Zrt.

Making Greener Cities (2004) Making Greener Cities. A Practical Guide. Leipzig, URGE-Team.

Ongjerth, R. (2008) Budapest zöldfelületi borítottságának vizsgálata (A survey of green surface coverage of Budapest). Falu-Város-Régió (Village(ity-Region), 15(1), pp. 27-30.

Schneller, I. (2008) Néhány gondolat Budapest 'zöld' ellátottságáról (Some thoughts about 'green' endowment of Budapest). Falu-Város-Régió (Village-City-Region), 15(1), pp. 13-16.

Tózsa, I. (1995) Budapest zöldterületeinek földrajzi áttekintése (Geographical review of green spaces in Budapest). Földrajzi Értesítő (Geographical Bulletin), 44(3-4), pp. 193-202.

Wassenberg, F., v. Meer, A., and v. Kempen, R. (2007) Strategies for upgrading the phisical environment in deprived urban areas - Examples of good practice in Europe. European Urban Knowledge Network (EUKN), Nicis Institute. Berlin, Bundesministerium für Verkehr, Bau und Stadtentwicklung.

Zahnen, B. (2004) Innerstädtische Grünflächen=kühl=entlastend? Eine Skizze zu klimatologischem Denken (Green spaces in city centre=cold= relieved? A contribution to climatic thought). Erdkunde 58(4), pp. 349-362. 